\title{
Bottle Roll Testing for Cyanidation of Gold Ores: Problems related to Standardized Procedures on Difficult-to-Process Ores
}

\author{
Mahir C. Cetin, N. Emre Altun, M. Ümit Atalay, K. Büyüktanır \\ Middle East Technical University \\ Mining Engineering Department, Ankara, Turkey \\ cmahir@metu.edu.tr, ealtun@metu.edu.tr, atalay@metu.edu.tr, karden@metu.edu.tr
}

\begin{abstract}
This paper evaluates the influence of some of the critical parameters of bottle roll testing procedure on gold extraction results and leaching behaviour. The conventional testing procedure with special emphasis to the testing duration, feed particle size, and $\mathrm{NaCN}$ concentration in the starting leach-solution, was assessed critically and compared with alternative approaches regarding these parameters. In conventional testing, test duration is typically 96-144 hours; test is conducted on finely ground feeds of usually -150 $\mu \mathrm{m}$; and test is started with a lixiviant that involves a $\mathrm{NaCN}$ concentration of usually $1 \mathrm{~kg} /$ tonne of ore, without identifying $\mathrm{NaCN}$ consumption tendency of the ore. Using results from three case studies, it was shown in this work that, applicability of these parameters without questioning/considering the specific features of a given Au ore is highly questionable: Test duration and feed particle size may have significant impacts on the measured Au extraction value, particularly with Au-ores that include preg-robbing matter and/or cyanicides. Au extraction and $\mathrm{NaCN}$ consumption profiles proposed that standardized application of bottle roll testing to challenging Au-ore types would yield misleading/overrated results. It was seen that extended testing periods on feeds that had equivalent particle size to field applications would yield more reliable estimation of field scale leaching behaviour. It was also shown that using a standard $\mathrm{NaCN}$ dosage in the starting lixiviant may be misleading, particularly for ores with cyanicides. A preliminary testing step to solely identify the $\mathrm{NaCN}$ consumption tendency of an Au-ore with cyanicides is suggested to accurately adjust the $\mathrm{NaCN}$ concentration of the initial leach-solution.
\end{abstract}

Keywords: Gold, Cyanide, Leaching, Bottle Roll Test, Preg-robbing, Cyanicide

\section{Introduction}

Cyanide leaching of gold is a very common methodology for evaluation of low grade gold ores. Despite risks associated with cyanide, the method proved to be highly effective provided that necessary precautions are taken. Gold cyanidation in field scale is mainly conducted through heap leaching and tank leaching methods. The choice between alternatives depend on several factors including grade of precious metals in the ore, size of the reserve, etc. Regardless of the method selection, the liability of the Au-bearing ore to cyanidation is the most critical aspect. In other words, the extraction possibility of gold from the given ore should be justified to consider/assess any leaching method for field scale operation. Testing a given ore in laboratory scale is essential to accurately identify its liability to cyanidation, leaching behaviour and kinetics as well as its tendency to consume cyanide. For laboratory testing and determination of cyanide leaching behaviour of Au-bearing ores, several methods have been proposed. Yet, bench-scale bottle roll testing has become a well-established procedure to gain preliminary insight about the leachability of a particular Au-bearing ore. The procedure seems straightforward, relatively easy to apply and is percepted to provide reliable and fast data that would form the basis for further assessment of a particular ore with respect to a prospective leaching process and scaling-up of leaching methods/procedures [1]. Based on these advantages, bottle roll tests were used in a vast number of previous work to estimate extent of Au-extraction and process design parameters, to evaluate performance of on-going leaching operations, to optimize leaching processes or to apply innovative approaches that would contribute to /enhance conventional leaching procedures [1-7] Despite these advantages, application of the procedure has several aspects that require specific attention and failure to meet these key points may lead to highly misleading results regarding the cyanidation behaviour and for developing a field-scale leaching strategy and process. Brittan also noted this fact, stating that the gold extraction in laboratory scale may be highly affected by the manner the tests are conducted and different result from the same ore could be easily achieved [6]. 
This paper highlights some of the most important aspects of this testing methodology and makes suggestions on some of the overseen phases in the test. In this respect, the duration of the test, particle size of the feed and the initial cyanide concentration and emphasized as three of the most critical parameters in designing a testing strategy. In the conventional approach, the test duration rarely exceeds 96 hours, i.e. leaching behaviour is monitored for a relatively short period. In some cases, test durations are kept as low as 24 hours [2]. Also, it almost became a standard procedure to conduct the test on finely ground ore (usually $-150 \mu \mathrm{m}$ or finer). Another common practice is using a lixiviant with a fixed initial $\mathrm{NaCN}$ concentration, which is usually $1 \mathrm{~kg} /$ tonne of ore without identifying cyanide consumption tendency of the ore. Applicability of these parameters without change/modification, i.e. anticipating that the standard application of the test would suit any Au-bearing ore is highly questionable. It was proposed that for free-milling, low cyanide consuming ores, results of a bottle roll test applied using commonly accepted parameters would approach field scale Au recovery. Yet, these standardized testing conditions/procedures may not be appropriate for difficult-to-process, high cyanide-, high oxygen consuming ores [1].

In this work, an attempt has been made to identify/clarify possible deviations when bottle roll testing is performed through the standardized conditions, especially when determining the leaching behaviour of hard-to-process ores. Accordingly bottle roll tests results from three specific cases were presented and discussed. In all cases leaching results obtained using the commonly accepted testing conditions and alternative testing conditions were compared and discussed.

\section{Experimental}

For the studied cases, Au-bearing ores from different regions of Türkiye were used and the sources of the ores are disclosed due to commercial restrictions. The ore used in the first case is characterized with its preg-robbing material content. Second ore is an ore with relatively higher liability to $\mathrm{NaCN}$ leaching whilst the third one features a significant extent of potential cyanide consuming components other than $\mathrm{Au}$ or $\mathrm{Ag}$, i.e. cyanicides.

For determining the leaching behaviour of the ores bench scale bottle roll tests were used. Common conditions for all the studied cases are as follows: Tests were conducted using ore slurries that consisted of 500 grams of representative ore and 1 liter of distilled water in 10 liter glass bottles. The size of the feed was $-150 \mu \mathrm{m}$, unless otherwise stated. The slurry $\mathrm{pH}$ was adjusted to $\geq 10.5$ using $\mathrm{Ca}(\mathrm{OH}) 2$ (Merck) and was maintained above this level throughout the tests. The initial $\mathrm{NaCN}$ (Merck) concentration was adjusted as $1 \mathrm{~kg} \mathrm{NaCN} /$ tonne ore unless otherwise stated. Bottle rolling rate is kept constant as 30-32 rpm in all tests. Other test conditions, which were subjected to change and/or which were alternatively applied to the standardized conditions are mentioned in the relevant parts of the next section. The pregnant solution was sampled after certain periods of leaching for analysis of $\mathrm{Au}$ extraction and $\mathrm{NaCN}$ consumption. Plotting the Au extraction and $\mathrm{NaCN}$ consumption data versus time yielded the leaching profile and cyanide consumption tendency of the ores. At all stages, the amount of dissolved $\mathrm{O} 2$ in the solutions were controlled and maintained above $4 \mathrm{mg} / \mathrm{l}$. Au content of the pregnant solutions were determined using a Shimadzu AA700 Atomic Adsorption Spectrometer. NaCN consumption by the ore was determined through the AgNO3-Rhodanin titration method, as described in details elsewhere [8-10].

\section{Results and Discussion}

\subsection{Case 1}

Figure 1 and 2 demonstrates the gold extraction and $\mathrm{NaCN}$ consumption profiles with time for the same ore. The ore was subjected to bottle roll testing to determine its liability to NaCN leaching. In accordance with the duration of a typical bottle roll tests, the test was terminated after 144 hours of leaching. Table $1 \& 2$ lists the extent of Au extraction and cumulative NaCN consumption by the ore after certain leaching periods, respectively, while Figure 1 demonstrates the overall leaching \& NaCN consumption of the ore in this test. The analysis showed that maximum Au extraction was achieved after 96 hours. At this point, Au extraction was 77.61\%. For this Au recovery, approximately $1 \mathrm{~kg} / \mathrm{tonne}$ ore $\mathrm{NaCN}$ was consumed. However, after a careful assessment of the leaching profile, a slight decrease in the amount of dissolved $\mathrm{Au}$ in the pregnant solution was figured out. Firstly, this reduction was attributed to slight experimental/analysis deviations while determining the amount of dissolved gold in the pregnant solutions. Then, repeating the test for an extended period, longer than typical testing times was decided. Figure 2 shows the results of the bottle roll testing of the same ore for 264 hours. The Au extraction profile was highly reproducible up to 144 hours in the second test, where Au extraction was $77.88 \%$ after 96 hours at $1.10 \mathrm{~kg} /$ tonne ore $\mathrm{NaCN}$ consumption. After 96 hours, the \% Au extracted tended to decrease. Normally, maximum Au extraction \% corresponds to the point where the NaCN leaching of gold comes to the 
end. After this maxima, stabilized Au extraction \%, i.e. a non-changing, straight leaching profile vs. time is anticipated. For this occasional case, though, approximately $12 \%$ decrease in dissolved Au was recorded from 96 hours to 264 hours. This significant loss is critically important, because bottle roll tests aim to simulate the field scale heap leaching of Au ores, where prolonged leaching periods as long as 3-6 months apply. In view of these observations, it was understood that the ore had certain mineralogical components that caused preg-robbing of dissolved gold from the pregnant solution. Regarding the possible field heap leaching implication for this ore, it could be deduced that, cyanidation of this ore would yield reasonable Au recoveries at the initial stages of leaching, but the process is very likely to be complicated by the mineralogical features and achieving reasonable gold recoveries may be challenging due to the preg-robbing components: As the leaching lixiviant finds its way through the heap from top to the bottom, some dissolved Au would be deducted from the pregnant solution. This test demonstrated that a detailed mineralogical investigation is essential for this particular ore. Table 3 presents some of the key compositional characteristics for this ore. Analysis showed that the ore had around $4.2 \%$ total carbon, $0.7 \%$ organic carbon, more than $4 \%$ sulphur, $3.22 \%$ iron and around $0.5 \%$ copper.

Table 1: Extent of gold extraction in tests $1 \& 2$ after certain leaching periods.

\begin{tabular}{|c|c|c|c|c|c|c|c|}
\hline & \multicolumn{7}{|c|}{ Sampling Time (hour) } \\
\cline { 2 - 8 } & 2 & 24 & 96 & 144 & 168 & 216 & 264 \\
\cline { 2 - 8 } & \multicolumn{7}{|c|}{ Au Extraction (\%) } \\
\hline Test 1 & 46.04 & 69.39 & 77.61 & 74.58 & - & - & - \\
\hline Test 2 & 44.44 & 70.59 & 77.88 & 74.92 & 72.73 & 67.25 & 65.75 \\
\hline
\end{tabular}

Table 2: Cumulative NaCN consumption in tests $1 \& 2$ after certain leaching periods.

\begin{tabular}{|c|c|c|c|c|c|c|c|}
\hline & \multicolumn{7}{|c|}{ Sampling Time (hour) } \\
\cline { 2 - 8 } & 2 & 24 & 96 & 144 & 168 & 216 & 264 \\
\cline { 2 - 8 } & \multicolumn{7}{|c|}{$\Sigma$ NaCN Consumption (g/tonne ore) } \\
\hline Test 1 & 0.20 & 0.64 & 1.04 & 1.06 & - & - & - \\
\hline Test 2 & 0.30 & 0.76 & 1.10 & 1.10 & 1.10 & 1.16 & 1.16 \\
\hline
\end{tabular}

Table 3: Quantities of critical elements in the ore.

\begin{tabular}{|c|c|c|c|c|c|c|c|c|c|c|}
\hline $\begin{array}{c}\mathrm{Au} \\
(\mathrm{g} / \mathrm{t})\end{array}$ & $\begin{array}{c}\mathrm{Ag} \\
(\mathrm{g} / \mathrm{t})\end{array}$ & $\begin{array}{c}\mathrm{C} \\
(\%)\end{array}$ & $\begin{array}{c}\text { Org. C } \\
(\%)\end{array}$ & $\begin{array}{c}\mathrm{S} \\
(\%)\end{array}$ & $\begin{array}{c}\mathrm{Fe} \\
(\%)\end{array}$ & $\begin{array}{c}\mathrm{Cu} \\
(\%)\end{array}$ & $\begin{array}{c}\mathrm{Ca} \\
(\%)\end{array}$ & $\begin{array}{c}\mathrm{Mg} \\
(\%)\end{array}$ & $\begin{array}{c}\mathrm{As} \\
(\%)\end{array}$ & $\begin{array}{c}\mathrm{Sb} \\
(\%)\end{array}$ \\
\hline 4.52 & 2.50 & 4.22 & 0.72 & 4.20 & 3.22 & 0.49 & 9.32 & 1.19 & - & - \\
\hline
\end{tabular}

Mineralogical investigations pointed to the presence of metallic sulphides, mainly in the form of pyrite $\left(\mathrm{FeS}_{2}\right)$ and chalcopyrite $\left(\mathrm{CuFeS}_{2}\right)$. Calcite $\left(\mathrm{CaCO}_{3}\right)$ and dolomite $\left(\mathrm{CaCO}_{3} \mathrm{MgCO}_{3}\right)$ were identified as major sources of carbon (other than organic carbon) in the ore. The preg-robbing effect of carbonaceous matter, i.e. organic carbon, in gold ores is very well established [5, 11-13]. In addition, presence of pyrite and chalcopyrite would have contributed to the loss of dissolved $\mathrm{Au}$ in the pregnant solution from this ore, as reported in previous studies [5, 12-14]. It should also be noted that, although this ore was not classified refractory, it should be treated as a complex Au-bearing one. In this respect, it was found critical that bottle roll tests should be continued for extended periods longer than the commonly typified testing times, to identify the possibility of such distinctive, unexpected leaching behaviour and loss of dissolved Au, particularly when indications for refractory/complex behaviour are implied by mineralogical/compositional investigations. 


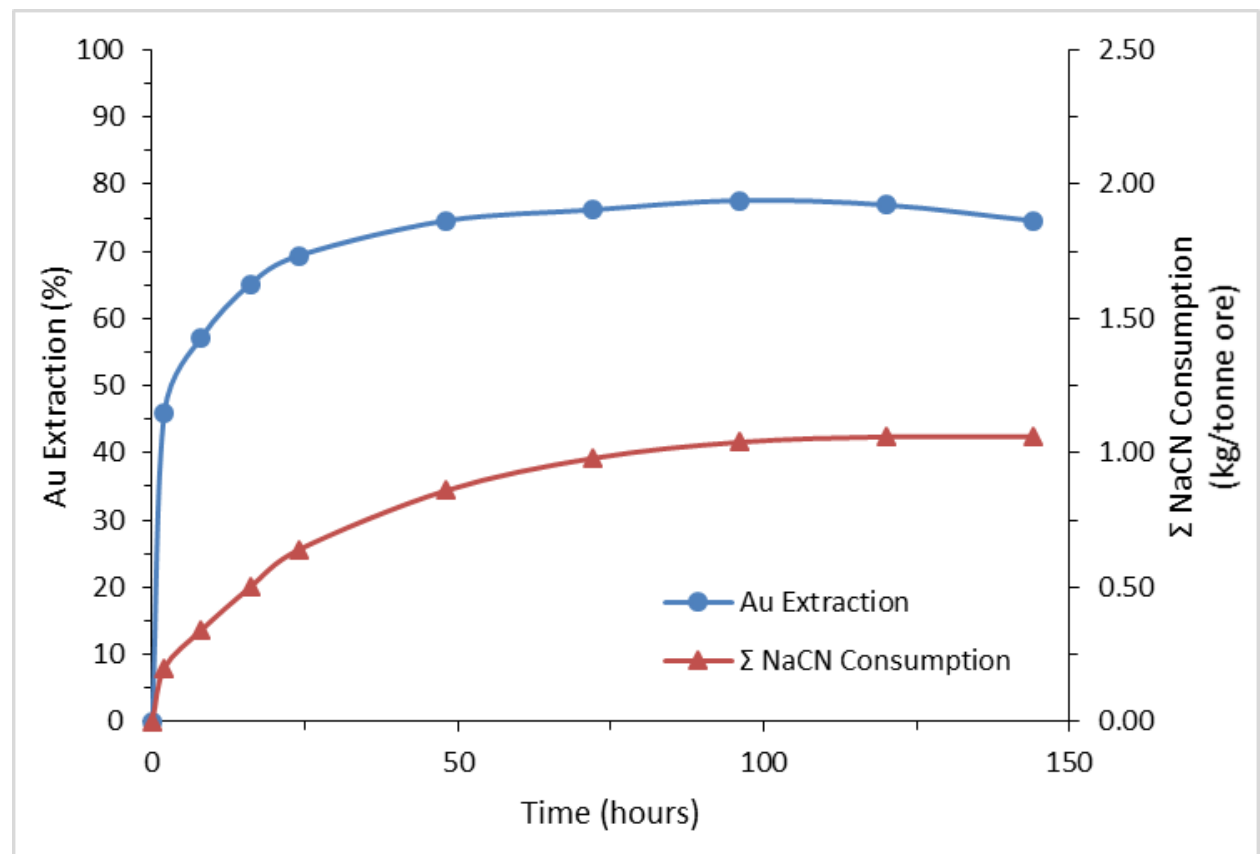

Fig. 1: Leaching profile of an Au-ore achieved by bottle roll testing for 144 hours.

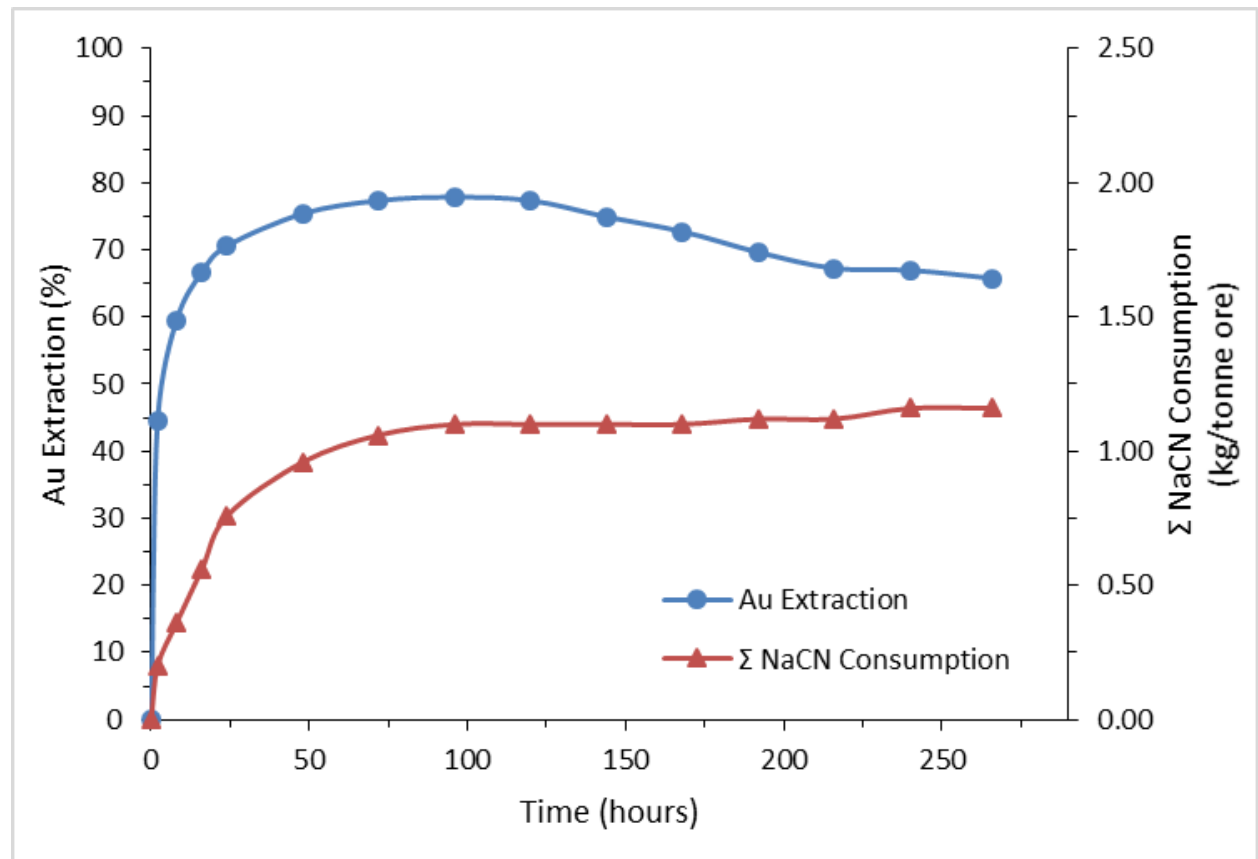

Fig. 2: Leaching profile of the same Au-ore achieved by bottle roll testing for 264 hours.

\subsection{Case 2}

Another case revealed the importance of the particle size of the feed to the bottle roll testing. The common practice is preparing a representative ore portion with a $\mathrm{P}_{100}$ size of $150 \mu \mathrm{m}$ as a feed to the test. It is percepted that at this particle size, the leaching performance identified approximates leaching behaviour of the given ore in the field. The actual case may be different than this assumption - at least for some gold ores and particle size of the feed would result in overrated $\mathrm{Au}$ extraction results that do not correspond to the Au recovery in the field. The presented case here shows this possibility: The ore comes from an ongoing heap leaching operation. It is characterized with a low Au content of 3 ppm and presence of an abundance of carbonate minerals. The full scale practice is based on crushing the ore to $100 \%$ passing $-10 \mathrm{~mm}$ size, 
pelletizing this crushed ore and preparing the heap using the ore pellets. On this ore, two groups of tests were conducted; First group included tests on feeds with the standard particle size of $-150 \mu \mathrm{m}$. In the second group, tests were conducted using feeds that had $-10 \mathrm{~mm}$ size, i.e. the size used in making pellets in the field. Other than the particle size all tests were conducted for 264 hours, using the same testing conditions. Figure 3 and 4 present results from two tests in these groups. Tables 4 \& 5 compares the Au extraction and $\mathrm{NaCN}$ consumption after certain periods of leaching. When the feed particle size was $-150 \mu \mathrm{m}$ maximum Au extraction was achieved after 72 hours as $92.72 \%$. To achieve this recovery $1.80 \mathrm{~kg} /$ tonne $\mathrm{NaCN}$ was consumed (Figure 3). This corresponds to an outstanding Au recovery at a reasonable NaCN consumption as well as favourable Au extraction kinetics. In other words, based on this leaching profile it was estimated that the ore is amenable to cyanidation and high Au recoveries would be expected from the full scale heap leaching operation. However, the leaching profile of the $-10 \mathrm{~mm}$ feed was quite different in all aspects (Figure 4, Tables $3 \& 4$ ). Maximum Au recovery was achieved after 168 hours. At this point, $75.75 \%$ Au was extracted with a NaCN consumption of $1.30 \mathrm{~kg} / \mathrm{tonne}$ ore. The results from the coarser feed implies that leaching proceeded more slowly and Au recovery was almost $17 \%$ lower. The Au recovery in the field from this heap leaching operation was in a range of 65-75\% through a one-year period. An overall evaluation of the field data and bottle roll test results, therefore, deduced that using a standard feed size of $-150 \mu \mathrm{m}$ in laboratory tests may easily produce over-promising results. The ore, actually, possesses the potential to yield a high Au recovery, as indicated by the test on the $-150 \mu \mathrm{m}$ feed - this was also justified by the higher amount of NaCN consumed by the $-150 \mu \mathrm{m}$ ore. However, at particle sizes practiced in full scale production, which are normally coarser, such recoveries may not be possible due to several reasons that would require further research and investigations.

Table 4. Extent of gold extraction at different feed sizes after certain leaching periods.

\begin{tabular}{|c|c|c|c|c|c|c|c|}
\hline \multirow{3}{*}{$\begin{array}{c}\text { Feed } \\
\text { Size }\end{array}$} & \multicolumn{7}{|c|}{ Sampling Time (hour) } \\
\hline & 2 & 24 & 72 & 120 & 168 & 216 & 264 \\
\hline & \multicolumn{7}{|c|}{ Au Extraction (\%) } \\
\hline$-150 \mu \mathrm{m}$ & 54.57 & 83.62 & 92.72 & 92.65 & 92.59 & 92.60 & 92.65 \\
\hline$-10 \mathrm{~mm}$ & 29.60 & 49.77 & 64.31 & 71.37 & 75.75 & 75.39 & 75.57 \\
\hline
\end{tabular}

Table 5. Cumulative NaCN consumption at different feed sizes after certain leaching periods.

\begin{tabular}{|c|c|c|c|c|c|c|c|}
\hline \multirow{3}{*}{$\begin{array}{c}\text { Feed } \\
\text { Size }\end{array}$} & \multicolumn{7}{|c|}{ Sampling Time (hour) } \\
\cline { 2 - 8 } & $\mathbf{2}$ & $\mathbf{2 4}$ & $\mathbf{7 2}$ & $\mathbf{1 2 0}$ & $\mathbf{1 6 8}$ & $\mathbf{2 1 6}$ & $\mathbf{2 6 4}$ \\
\cline { 2 - 8 } & \multicolumn{7}{|c|}{$\mathbf{\Sigma}$ NaCN Consumption (g/tonne ore) } \\
\hline$-150 \mu \mathrm{m}$ & 0.45 & 1.25 & 1.80 & 2.05 & 2.10 & 2.10 & 2.10 \\
\hline$-10 \mathrm{~mm}$ & 0.20 & 0.50 & 0.94 & 1.20 & 1.30 & 1.30 & 1.30 \\
\hline
\end{tabular}

\subsection{Case 3}

Another standardized procedure in bottle roll testing is using a starting leach-solution that includes a fixed $\mathrm{NaCN}$ concentration, which is generally $1 \mathrm{~kg} /$ tonne ore $\mathrm{NaCN}$. After certain periods, the $\mathrm{NaCN}$ consumption is determined and consumed amount of $\mathrm{NaCN}$ is readded to the leach-solution to reconstitute the initial $\mathrm{NaCN}$ dosage of $1 \mathrm{~kg} / \mathrm{tonne}$. This starting dosage is ideal in several cases, especially when the tested ore is of free-milling type or at least when it is anticipated amenable to cyanidation. Yet, for complex Au ores, refractory Au-ores and/or Au-ores with cyanicides, it may be erroneous to presume $1 \mathrm{~kg} /$ tonne $\mathrm{NaCN}$ as a sufficient dosage in the initial leaching solution. Based on our observations on vast number of bottle roll tests on varying Au ore types, it was proposed to conduct a series of preliminary tests using initial leach-solutions that include different $\mathrm{NaCN}$ dosages. This series of tests is highly useful to specifically determine the correct $\mathrm{NaCN}$ dosage to be added in the initial leaching solution. Figure 5 and 6 present results for such a testing strategy on a highly refractory Au-ore that also included a significant amount of cyanicides like pyrite and arsenic sulphides, realgar and orpiment. The compositional characteristics of the tested ore is shown in Table 6. 


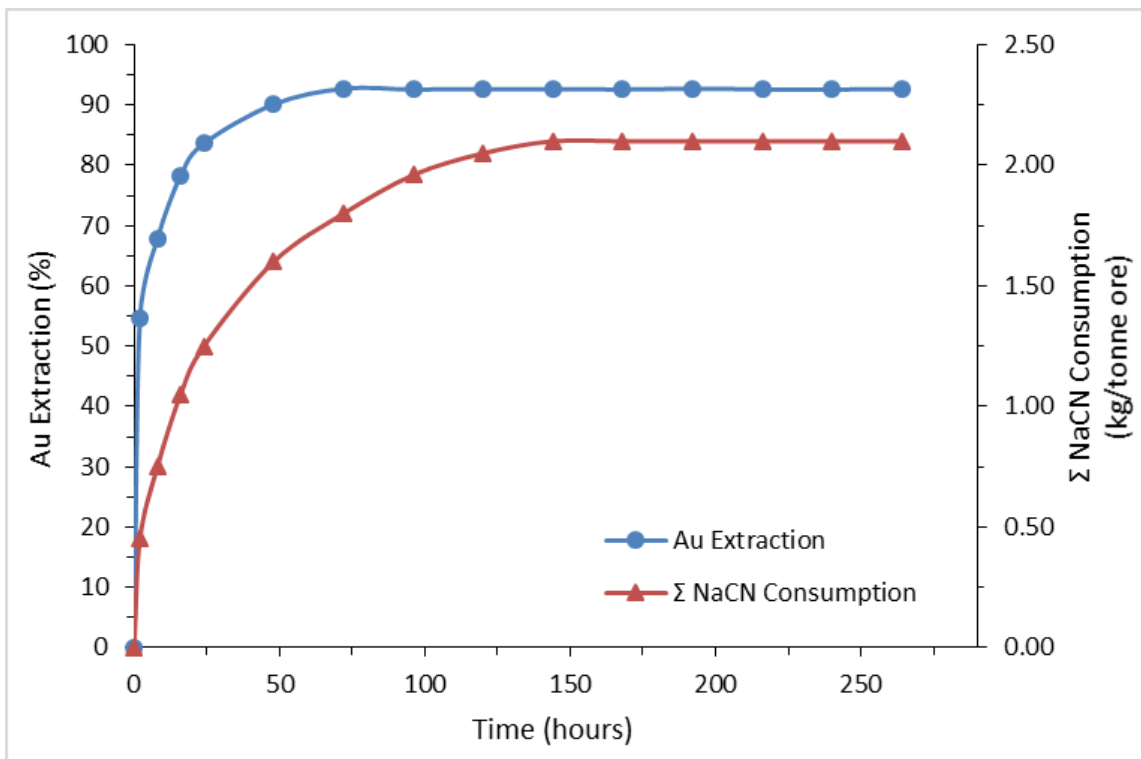

Fig. 3: Leaching profile of a relatively free-milling Au-ore by bottle roll testing on $-150 \mu \mathrm{m}$ feed.

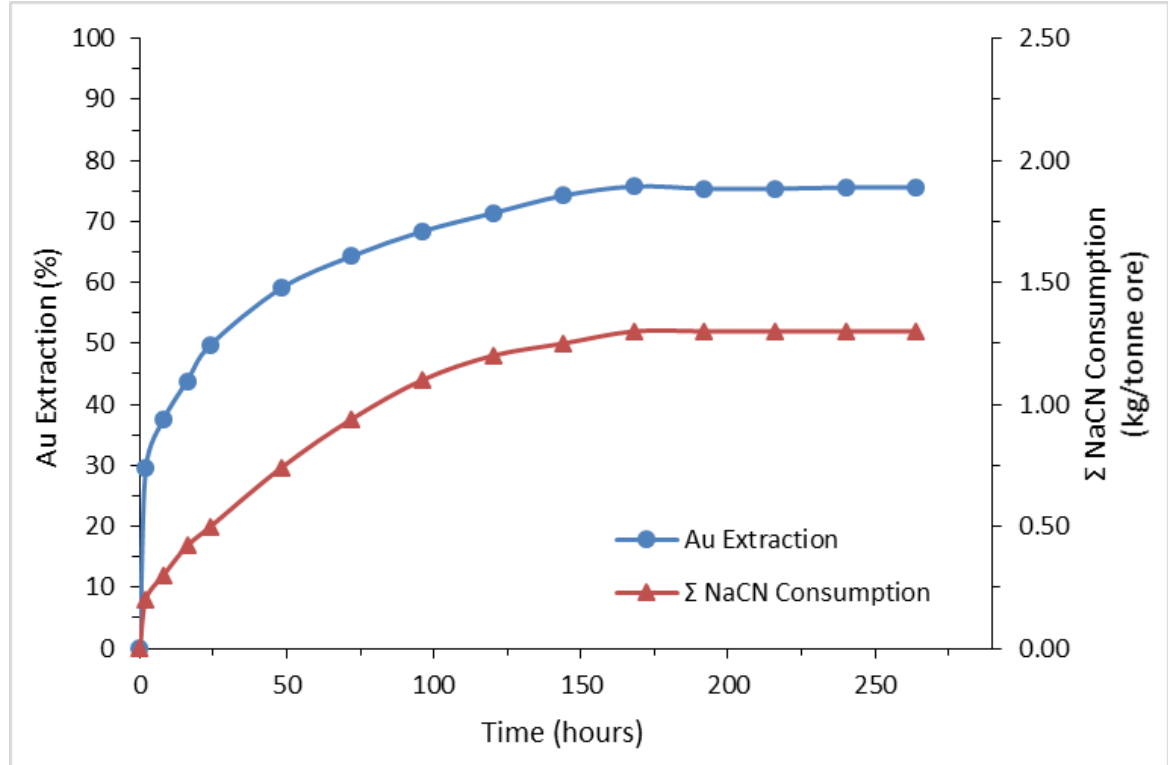

Fig. 4: Leaching profile of a relatively free-milling Au-ore by bottle roll testing on $-10 \mathrm{~mm}$ feed.

Table 6: Composition of a highly refractory Au-bearing ore with extensive cyanicides content.

\begin{tabular}{|c|r|c|r|}
\hline Compound & \multicolumn{1}{|c|}{$\%$} & Element & \\
\hline $\mathrm{SiO}_{2}$ & 56.12 & $\mathrm{Au}$ & $2.50 \mathrm{ppm}$ \\
\hline $\mathrm{CaO}$ & 19.12 & $\mathrm{Ag}$ & $2.00 \mathrm{ppm}$ \\
\hline $\mathrm{Al}_{2} \mathrm{O}_{3}$ & 3.20 & $\mathrm{Cu}$ & $750 \mathrm{ppm}$ \\
\hline $\mathrm{Fe}_{2} \mathrm{O}_{3}$ & 1.12 & $\mathrm{~Pb}$ & $362 \mathrm{ppm}$ \\
\hline $\mathrm{K}_{2} \mathrm{O}$ & 0.16 & $\mathrm{Zn}$ & $250 \mathrm{ppm}$ \\
\hline $\mathrm{MnO}$ & 0.20 & $\mathrm{Mo}$ & $6.5 \mathrm{ppm}$ \\
\hline $\mathrm{MgO}$ & 0.20 & $\mathrm{As}$ & $5.52 \%$ \\
\hline & & $\mathrm{S}$ & $7.52 \%$ \\
\hline
\end{tabular}


In this test series four different lixiviants were prepared with 500, 1000, 1500, $2000 \mathrm{ppm} \mathrm{NaCN}$ and separate bottle roll tests were conducted using these starting leach-solutions. In the first test, a majority of $500 \mathrm{ppm} \mathrm{NaCN}$ was consumed by the ore at the end of 30 minutes. Yet, Au extraction was very limited (7\%). This indicated that 500 ppm was not sufficient as an initial $\mathrm{NaCN}$ concentration. Further 30 minutes was not long enough for completing Au extraction. Second test was started at an initial $\mathrm{NaCN}$ concentration of $1000 \mathrm{ppm} .1000 \mathrm{ppm} \mathrm{NaCN}$ was entirely consumed after 120 minutes of leaching and at this point gold extraction reached 12.5\%. When compared with the first test with 500 ppm NaCN, leaching continued for a longer period, up to 120 minutes in the second test and Au extraction increased by 4.5\%. However, based on the $\mathrm{Au}$ leaching profile vs. time at this $\mathrm{NaCN}$ concentration, it was concluded that an initial $\mathrm{NaCN}$ concentration of $1000 \mathrm{ppm}$ was again not sufficient, i.e. leaching of Au was likely to continue provided that the starting leach-solution had higher $\mathrm{NaCN}$ dosage. Accordingly, further increase of $\mathrm{NaCN}$ concentration to $1500 \mathrm{ppm}$ in the starting leach-solution was attempted. With $1500 \mathrm{ppm} \mathrm{NaCN}$, Au extraction increased to 16.6\% after 120 minutes (Figure 5). At this point, the cyanide was almost entirely consumed.

Also, leaching tended to slow down after 90 minutes; i.e. despite ongoing $\mathrm{NaCN}$ consumption, the rate of $\mathrm{Au}-$ extraction decreased in the 90-120 minutes range. Obtaining higher Au-extractions in all periods as compared to the test with $1000 \mathrm{ppm}$ further justified that $1000 \mathrm{ppm}$ was insufficient as an initial $\mathrm{NaCN}$ concentration for bottle roll testing of this ore. To verify if the highest extent of Au leaching was achieved, a final test was conducted by increasing the $\mathrm{NaCN}$ concentration in the initial leach solution to $2000 \mathrm{ppm}$. Increasing $\mathrm{NaCN}$ concentration from $1500 \mathrm{ppm}$ to $2000 \mathrm{ppm}$ did not enhance Au-extraction and leaching was almost completed after 120 minutes. This is a similar leaching profile with that obtained using $1500 \mathrm{ppm} \mathrm{NaCN}$. Au extraction at this point was $16.9 \%$, a similar Au extraction value obtained with $1500 \mathrm{ppm} \mathrm{NaCN}$ (Figure 5). After 120 minutes NaCN consumption was almost stabilized, also confirming that leaching came to an end: Extending the leaching beyond 180 minutes did not increase Au extraction or NaCN consumption (Figures 5 \& 6). Very low $\mathrm{Au}$ extraction and high levels of $\mathrm{NaCN}$ consumption were characteristics of this ore, which are distinctive features of highly refractory Au-ores that include cyanicides [5, 15]. NaCN consumption vs. time profiles revealed that for this ore complete leaching cannot be achieved with $500 \mathrm{ppm}$ and $1000 \mathrm{ppm} \mathrm{NaCN}$ in the initial leach solutions. $2000 \mathrm{ppm} \mathrm{NaCN}$, though, was seen to be an excessive cyanide dosage and Au extraction does not increase with $2000 \mathrm{ppm} \mathrm{NaCN}$ as compared to the results with 1500 ppm cyanide (Figure 5). In this respect, $1500 \mathrm{ppm} \mathrm{NaCN}$ was proposed as the ideal concentration for the starting leach-solutions. This value corresponded to a NaCN addition of 2250 $\mathrm{g} /$ tonne ore and is obviously higher than the commonly applied starting $\mathrm{NaCN}$ concentration of $1000 \mathrm{~g} /$ tonne ore.

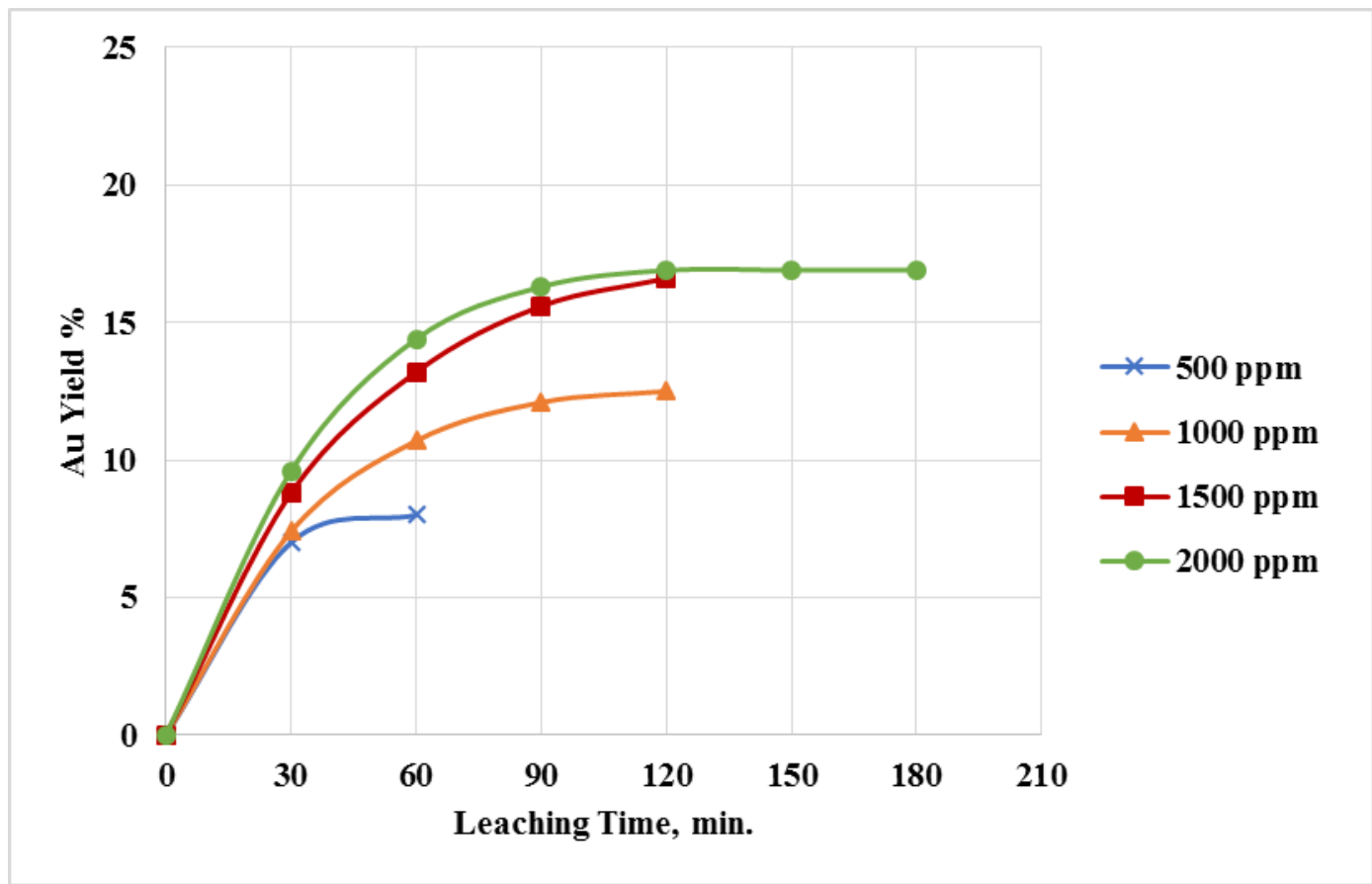

Fig. 5: Au recovery w.r.t different $\mathrm{NaCN}$ concentrations in the initial leach solution. 


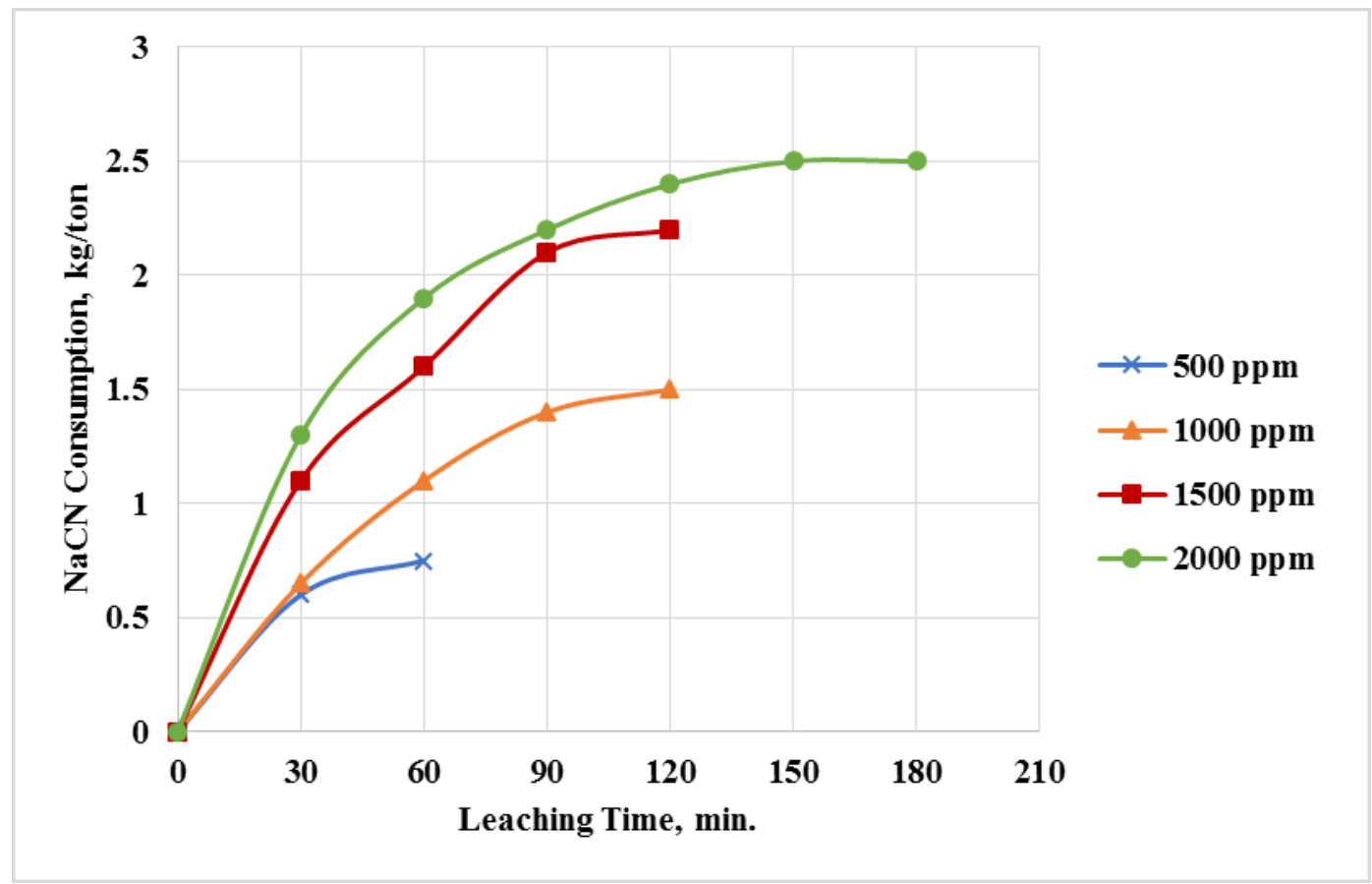

Fig. 6: NaCN consumption vs. leaching time for different $\mathrm{NaCN}$ concentrations in the initial leach solution.

\section{Conclusions}

Overall, despite the reliability of the bottle roll testing on gaining preliminary knowledge about the amenability of a given Au-ore to cyanidation, application of standardized testing conditions may fail to mimic prospective leaching behaviour in field scale. This hypothesis was confirmed by the results presented in this work, especially for difficult-toleach refractory or complex Au-ore types, where the anticipated gold extraction is interfered and/or obscured by various aspects such as presence of cyanicides, preg-robbing components, etc. For such ores, the testing procedure may still be effectively used, but the well-established testing conditions are subject to change and should be adapted to encounter the specific challenges that would potentially influence the leaching behaviour of the ore.

\section{References}

[1] M. Brittan and G. Plenge, "Estimating process design gold extraction, leach residence time and cyanide consumption for high cyanide-consuming gold ore," Miner. Metall. Proc., vol. 32, pp. 111-120, 2015.

[2] C. Williams and J. Robinson, "A comparison of gold recovery by pressure cyanidation and by pressure oxidation/conventional cyanidation from a stibnite concentrate," in Fifth AuslMM Extractive Metallurgy Conference, Perth, 1991.

[3] C. H. Sampaio, C. O. Petter, R. M. Kautzmann and S. L. Klein, "Technological characterization of Riacho Dos Machados gold ore for cyanide leaching and study of the utilization of oxidising agents," Miner. Eng., vol. 10, no. 5, pp. 547-550, 1997.

[4] A. N. Nikoloski and N. Stockton, "Application of alternative lixiviants for secondary heap leaching of gold," in Seventh Mill Operators' Conference, AusIMM, Kalgoorlie, 2000.

[5] J. O. Marsden and C. I. House, The Chemistry of Gold Extraction. $2^{\text {nd }}$ Ed., SME, 2006.

[6] M. I. Brittan, "Kinetic and equilibrium effects in gold ore cyanidation," Miner. Metall. Proc., vol. 25, no. 3, pp. 117$122,2008$.

[7] P. A. Roberts, H. Zhang, H. Prommer, B. Benvie, M. I. Jeffrey, C. D. Johnson and R. R. Anand, "Ore characterization, hydrometallurgical and rteactive transport studies for in-place leaching of oxidized gold deposits," Miner. Metall. Proc., vol. 27, no. 2, pp. 72-80, 2010. 
[8] J. A. Ryan and G. W. Culshaw, "The Use of $\mathrm{p}$-Dimethylaminobenzylidene Rhodanine as an Indicator for the Volumetric Determination of Cyanides," Analyst, vol. 69, pp. 370-371, 1944.

[9] P. L. Breuer, C. A. Sutcliffe and R. L. Meakin, "Cyanide measurement by silver nitrate titration: Comparison of rhodanine and potentiometric end-points," Hydromet., vol. 106, pp. 135-140, 2011.

[10] J. C. Van Loon and R. R. Barefoot, Analytical Methods for Geochemical Exploration. Toronto: Akademie Press, 1989.

[11] M. D. Adams and A. M. Burger, "Characterization and blinding of carbonaceous preg-robbers in gold ores," Miner. Eng., vol. 11, no. 10, pp. 919-927, 1998.

[12] B. Nanthakumar, C. A. Pickles and S. Kelebek, "Microwave pretreatment of a double refractory gold ore," Miner. Eng., vol. 20, pp. 1109-1119, 2007.

[13] J. D. Miller, R.-Y. Wan, X. Diaz, "Preg-robbing gold ores," in Gold Ore Processing, M.D. Adams, Ed. Elsevier Science, 2016, pp. 885-907.

[14] K. L. Rees and J. S. J van Deventer, "Preg-robbing phenomena in the cyanidation of sulphide gold ores," Hydromet., vol. 58, pp. 61-80, 2000.

[15] D. Lunt, N. Briggs, "Refractory sulfide ores - Case studies," in Gold Ore Processing, M.D. Adams, Ed. Elsevier Science, pp. 873-883, 2016. 